\title{
Theater of the Oppressed and bullying: nursing performance in school adolescent health
}

\author{
Teatro do Oprimido e bullying: atuação da Enfermagem na saúde do adolescente escolar \\ Teatro del oprimido y el bullying: el desempeño de enfermería en la salud escolar de los adolescentes
} Lidiane Cristina da Silva Alencastro'
ORCID: 0000-0003-3005-415X

Jorge Luiz da Silva ${ }^{1,11}$ ORCID: 0000-0002-3727-8490

André Vilela Komatsu' ORCID: 0000-0001-8508-6787

Fabiane Blanco Silva Bernardino"' ORCID: 0000-0003-0339-9451

Flávia Carvalho Malta de Mello' ORCID: 0000-0001-5019-8316

Marta Angélica lossi Silva' ORCID: 0000-0002-9967-8158

'Universidade de São Paulo. Ribeirão Preto, São Paulo, Brazil. "Universidade de Franca. Franca, São Paulo, Brazil. "'Universidade Federal de Mato Grosso. Cuiabá, Mato Grosso, Brazil.

How to cite this article: Alencastro LCS, Silva JL, Komatsu AV, Bernardino FBS, Mello FCM, Silva MAI. Theater of the Oppressed and bullying: nursing performance in school adolescent health. Rev Bras Enferm. 2020(1);73:e20170910. doi: http://dx.doi.org/10.1590/0034-7167-2017-0910

\section{Corresponding Author:}

Lidiane Cristina da Silva Alencastro

E-mail: lidiane.alencastro@gmail.com

EDITOR IN CHIEF: Dulce Aparecida Barbosa ASSOCIATE EDITOR: Cristina Parada

Submission: 01-16-2018

Approval: 08-18-2018

\section{ABSTRACT}

Objective: to assess the effects of an intervention based on the Theater of the Oppressed in reducing school bullying. Method: a quasi-experimental study with 232 first-year high school students from two public schools in the city of Cuiabá, Mato Grosso State, Brazil. An intervention was performed with the Theater of the Oppressed, a theatrical methodology created by Augusto Boal and inspired by Paulo Freire's "Pedagogy of the Oppressed", in which one school composed the intervention group, and another school, the comparison group. Both groups were assessed for involvement in bullying situations before and after intervention. For data analysis, Poisson Regression models with random effect were used. Results: intervention group presented a significant decrease in direct victimization (physical and verbal aggression). Conclusion: the Theater of the Oppressed represents an important strategy in reducing bullying victimization among school adolescents.

Descriptors: Bullying; Violence; Nursing; Adolescent; Adolescent Health.

\section{RESUMO}

Objetivo: avaliar os efeitos de uma intervenção baseada no Teatro do Oprimido na redução do bullying escolar. Método: estudo quase-experimental, realizado com 232 estudantes do primeiro ano do Ensino Médio de duas escolas públicas da cidade de Cuiabá-MT. Realizouse uma intervenção com o Teatro do Oprimido, metodologia teatral criada por Augusto Boal e inspirada na obra "Pedagogia do Oprimido" de Paulo Freire, em que uma escola compôs o grupo de intervenção, e a outra escola, o grupo de comparação. Ambos os grupos foram avaliados quanto ao envolvimento em situações de bullying antes e depois da realização da intervenção. Para análise dos dados, utilizaram-se modelos de Regressão de Poisson com efeito aleatório. Resultados: o grupo de intervenção apresentou redução significativa na vitimização direta (agressões físicas e verbais). Conclusão: o Teatro do Oprimido representa uma estratégia importante na redução da vitimização por bullying entre adolescentes escolares.

Descritores: Bullying; Violência; Enfermagem; Adolescente; Saúde do Adolescente.

\section{RESUMEN}

Objetivo: evaluar los efectos de una intervención basada en el Teatro del Oprimido para reducir el bullyig escolar. Método: un estudio cuasi experimental con 232 estudiantes de primer año de secundaria de dos escuelas públicas en la ciudad de Cuiabá, estado de Mato Grosso. Se realizó una intervención con el Teatro del Oprimido, una metodología teatral creada por Augusto Boal e inspirada en la "Pedagogía del Oprimido" de Paulo Freire, en la que una escuela compuso el grupo de intervención y otra escuela, el grupo de comparación. Ambos grupos fueron evaluados por su participación en situaciones de bullying antes y después de la intervención. Para el análisis de los datos, utilizamos modelos de regresión de Poisson con efecto aleatorio. Resultados: el grupo de intervención presentó una reducción significativa en la victimización directa (agresión física y verbal). Conclusión: el Teatro del Oprimido representa una estrategia importante para reducir la victimización por bullying entre los adolescentes escolares.

Descriptores: Bullying; Violencia; Enfermería; Adolescente; Salud del Adolescente. 


\section{INTRODUCTION}

Adolescence involves several changes in physical, emotional and social aspects ${ }^{(1)}$. This process has different interpretations, varied conceptualizations that highlight its vulnerabilities and potentialities. It is a complex, historically and socially constructed period of development in which risk behaviors can be manifested, such as the use of illicit substances, unprotected sexual intercourse, situations of violence, infringing behavior, among others ${ }^{(2-3)}$. Among these behaviors, violence among peers in schools stands out due to its high occurrence rate ${ }^{(4)}$. As adolescents spend much of their daily time in school, conflict situations and bullying can become recurrent in interactions with peers ${ }^{(5)}$.

Bullying is a type of school violence characterized by repetitive, intentional, unmotivated actions involving power imbalance between victims and perpetrators ${ }^{(6)}$. It can manifest itself through direct aggression and victimization, which is represented by the action of practicing and / or suffering: provocations, fights, shoves, punches, kicks and cursing. Relational aggression and victimization are characterized by actions of excluding from groups and/or jokes, nicknaming, spreading rumors about colleagues to make others laugh and encouraging fights. Indirect aggression and victimization are characterized by the actions of stealing or tampering with the belongings of colleagues ${ }^{(7)}$. The average occurrence of bullying in Brazilian schools is $28 \%{ }^{(8)}$, above the average of countries such as Greece (16.0\%), Spain (17.4\%), Finland (18.2\%) and the United States $(24.5 \%)^{(9)}$.

Studies have pointed out that the negative effects of bullying can directly affect involved students on their physical health (bruises and injuries, for example) and mental health (sadness, depression, low self-esteem and suicidal thoughts, among others) as well as in social relationships (isolation) and in school performance (non-learning, low grades and school dropout ${ }^{(6,10)}$. Given this setting, it is important to develop strategies that help reduce and prevent this type of violence through interventions that promote good social interaction, self-esteem and cooperative conflict resolution ${ }^{(11)}$.

Considering the magnitude and results presented in current studies on bullying in schools $s^{(8,12-13)}$, and understanding nursing as a social practice, the conduction of this study is proposed, which enters into the field of some unexplored tensions.

The first one can be found at the school nurse's own work, in the health and nursing team's practice, with the "violence" theme, aiming at preventing this grievance in schools and promoting health. The second refers to the fact that, historically, we have been working in schools with individual and curative care issues in detriment of social transformation processes that combine the collective good; and, finally, the normalized and cheapened conception of peer violence, obscured by the fashion of different educational styles, of supposedly expected behaviors, and of tolerance toward negative behavior.

It is from the tendency to include bullying within the broader programs of violence prevention, including its genesis in sociocultural processes ${ }^{(14)}$, that there is an association between the proposition of an intervention program linked to health strategy promotion and nursing care integrality in schools. This model was denominated as emancipatory, since it seeks the empowerment and participation of subjects involved.
An intervention modality that has been developed internationally by nurses, aiming at the prevention of and coping with school bullying is dramatization. It enables the subjects to be involved in socialization of experiences and employs resources such as speech, art, body movement, all of which favor access to affective and emotional levels through artistic, verbal and corporal language, as well as being able to decode transmitted information and participant perception ${ }^{(15-16)}$. A theater-based intervention developed in Finland with fifth-year students improved empathy, pro-social behavior, understanding about diversity, and about consequences of bullying ${ }^{(17)}$. A similar study was developed in the United States to promote healthy relationships among eighth grade students, to prevent bullying and peer violence. The students pointed out that the intervention would change their future behaviors in relation to the themes that dealt with in the presentations ${ }^{(18)}$.

However, none of the reported interventions were based on the Theater of the Oppressed, a theatrical technique created by Augusto Boal in the 70's, aiming at breaking the dichotomy between theater and audience and thus promoting a theater with the involvement of all ${ }^{(19)}$. This technique was inspired by Paulo Freire's "Pedagogy of the Oppressed", which analyzes political, social and pedagogical consequences of different forms of human relations, conceiving a human and liberating pedagogical method in which the oppressed reveal the world of oppression through transformation of their practice and, in a second moment, the oppressive reality ${ }^{(20)}$. Theater of the Oppressed, by incorporating Freire's thoughts, advocates for dialogue and cooperation in the quest to problematize, understand and transform reality ${ }^{(20)}$, aiming at giving voice and power to any person or group that suffers some type of oppression ${ }^{(21)}$, such as bullying victims.

\section{OBJECTIVE}

To assess the effects of an intervention based on the Theater of the Oppressed in reducing school bullying.

\section{METHOD}

\section{Ethical aspects}

The study was approved by the Research Ethics Committee of Universidade de São Paulo's Escola de Enfermagem de Ribeirão Preto (EERP/USP). Guardians of adolescents under 18 years old allowed their participation through the signing of a Free and Informed Consent Term (FICT). Adolescents expressed their agreement to participate in the study by signing the Term of Assent.

\section{Design, place of study and period}

It is a quasi-experimental study, since it does not have all the characteristics of an experimental study, mainly in what refers to randomization and equivalent composition between experimental group and control group ${ }^{(22)}$. Data collection was carried out in two public schools in the city of Cuiabá, capital of Mato Grosso State. One school formed the intervention group, in which the technique of Theater of the Oppressed was used. The other 
school was the comparison group, which did not participate in the activities proposed in the intervention. Groups were assessed as to student involvement in bullying situations before and after dramatization with Theater of the Oppressed in the intervention school, in order to assess the effect of intervention in reducing bullying. Data collection took place in 2016, pre-intervention assessment was performed in October, Theater of the Oppressed was performed from October to November, and post-intervention assessment was performed in December.

\section{Study population and inclusion criteria}

The study enrolled 232 students from the first year of high school, because this is a period of transition from elementary school to high school, which shows a higher occurrence of bullying ${ }^{(10)}$. Inclusion criteria were: to be present at data collection's pre-intervention time, to be adolescent (aged between 10 and 19 years according to World Health Organization - WHO) and to have parental or foster care authorization to include those adolescents under 18 years of age. Hence, adolescents who met the inclusion criteria and wished to participate in the study were eligible for the study. There was no loss between the pre- and post-intervention phase.

\section{Protocol}

Intervention was composed of two phases, the first being a moment of approximation between the researcher and the subjects of the study and of their sensitization in relation to bullying. At this stage, adolescents participated in group games belonging to the Theater of the Oppressed, which were applied in a single time, in workshop format, with each of the 10 first-year classes of the intervention school, with an average duration of one hour and twenty minutes in each class.

Augusto Boal, in his book"Jogos para atores e não atores" divided his games into five categories: the first seeks to reduce the distance between feeling and playing; the second, between listening and hearing; the third seeks to develop the various senses at the same time; in the fourth, one tries to see everything one looks at, and in the fifth category, the purpose is to awaken and work memory ${ }^{(23)}$. Furthermore, the first phase of the intervention contemplated, on a growing scale, games of all categories. Therefore, after implementation of theatrical games, a list was made with the names of students interested in participating in the structuring and presentation of the staging that composed the second moment of the intervention.

From the list of students interested in participating in the staging, two organizing teams were formed, each presenting its theatrical representation for the five classes, of which they were not part, offering them the opportunity to be "spect-actors" (denomination created by Boal for spectators that can intervene in the performance) in the other presentation. In this way, the second moment of the intervention was the organization of a theatrical play about bullying, written by adolescents themselves, in which the staged subjects and situations had their origin in the participants' own experience. The most important thing was to involve adolescents in dramatization and problematization of situations that they experienced, which departed from their needs and that made sense to them.
Thus, they presented the main situations they experienced, challenges they faced in overcoming the situation, the way they felt, negative consequences of violence, and ways to overcome them. Among other modalities of the Theater of the Oppressed, the Theater Forum technique was selected, which refers to the dramatization of real situations, permeated by conflicts, in which spectators, named by Augusto Boal as "spect-actors", are invited to participate in the staging, in order to develop solutions and ways to overcome oppression ${ }^{(21)}$.

In this way, staging, in the first instance, was presented in a conventional way, in which it was shown a certain situation of bullying, as an oppression that one wishes to combat. It was then asked if the "spect-actors" were in agreement with the solution proposed by the protagonist in the scene. From then on, the relay began with the protagonist, in which ideas, experiences, experiences and solutions of confrontation proposed by the "spect-actors" were presented. The intervention had a total duration of two months, performed on alternate days. Thus, there were 16 effective days of intervention, in which four of them were destined to the meetings with the organization groups of the staging. Games took place in ten days, and stage play was presented in two. The whole process of staging the Theater Forum, from production to presentation, was mediated by one of the researchers, who has training on the Theater of the Oppressed.

In order to evaluate students' involvement in bullying situations, the Peer Victimization and Aggression Scale (EVAP - Escala de Agressão e Vitimização entre Pares) ${ }^{(7)}$ was used. It is a validated tool in Brazil, composed of 18 questions related to bullying behaviors in school environment, whose application can be carried out with students from the $6^{\text {th }}$ year of elementary school to the $3^{\text {rd }}$ year of high school. A sociodemographic characterization questionnaire, elaborated for this research, was applied.

\section{Analysis of results, and statistics}

Data analysis was performed using descriptive statistics (average and Standard Deviation). The Chi-Square test was used to measure the association between categorical variables. In order to compare the variables of aggression and victimization with respect to time (pre and post) and schools (comparison and intervention), the Poisson Regression model was used with random effect. The analysis was performed using the SAS 9.3 program. A significance level of $5 \%$ was considered for all analysis, $p<0.05$.

\section{RESULTS}

Among the 232 adolescents investigated, 134 (57.8\%) comprised the intervention group ( $\mathrm{Gl}$ ) and 98 (42.2\%) were the comparison group (CG). The two groups were equivalent in relation to the number of boys, with $54.5 \%$ in Gl and $55.1 \%$ in CG. Regarding age, the majority of IG participants were 15 years old (57.1\%). In CG, the prevailing age was 16 years (44.33\%), a difference that was not statistically significant $(\mathrm{p}=0.0666)$. Skin color was similar in the groups ( $p=0.0823)$. IG: brown $(55.6 \%)$, black $(27.1 \%)$, white (15.0\%) and yellow (2.3\%). CG: brown (59.8\%), black (21.6\%), white (11.3\%), yellow (2.1\%) and indigenous (2.2\%). 
Table 1 shows the differences obtained by the Poisson Regression model for the variables in relation to aggression and victimization in pre- and post-intervention moments.

Table 1 - Comparison between (intervention and comparison) groups in relation to aggression and victimization in the pre- and post-intervention moments through Poisson Regression, Cuiabá, Mato Grosso, Brazil, 2016

\begin{tabular}{lcccc}
\hline & \multicolumn{2}{c}{ Intervention (n=134) } & \multicolumn{2}{c}{ Comparison $(\mathbf{n}=\mathbf{9 8})$} \\
& Pre-intervention & Post-intervention & Pre-intervention & Post-intervention \\
\hline Direct aggression & $9.55(3.82)$ & $9.31(3.88)$ & $10.42(3.93)$ & $10.20(3.78)$ \\
Relational aggression & $7.43(3.58)$ & $7.35(3.33)$ & $8.02(3.57)$ & $7.74(3.85)$ \\
Indirect aggression & $1.29(0.89)$ & $1.19(0.65)$ & $1.29(0.80)$ & $1.43(1.06)$ \\
Direct victimization & $7.75(3.43)^{*}$ & $7.00(3.07)^{*}$ & $8.69(3.38)$ & $9.00(3.35)$ \\
Relational victimization & $5.91(3.00)$ & $5.96(3.23)$ & $6.58(3.27)$ & $6.84(2.99)$ \\
Indirect victimization & $1.93(1.27)$ & $1.89(1.17)$ & $2.43(1.31)$ & $2.24(1.30)$ \\
\hline
\end{tabular}

Note: data presented on average (Standard Deviation); ${ }^{*}=p<0.05$.

The results indicated a non-significant reduction in direct aggression in IG and CG. Relational aggression also did not reduce meaningfully in both groups. However, indirect aggression decreased in the IG and increased in the CG, but at non-significant levels. It is worth noting that IG presented a significant reduction in direct victimization $(\beta=0,102, S E=0.045, p=0.02)$, whereas in CG there was an increase, although not significant. Relational victimization increased for IG and CG at nonsignificant levels. Indirect victimization decreased not meaningfully in the two groups.

\section{DISCUSSION}

The objective of this study was to evaluate the effects of an intervention based on the Theater of the Oppressed, in the decrease of school bullying. The results indicated that the occurrence of aggression and direct victimization was greater in relation to relational and indirect aggression and victimization, in both groups investigated (intervention and comparison). Similar results were identified by another national study conducted in public schools in one state of the South of Brazil, which identified that direct (physical) aggressions were more prevalent than psychological (relational) aggressions ${ }^{(24)}$. This situation is different from that found in two studies conducted in the United States with public school students in which the means of relational victimization and aggression were higher than the means of physical victimization and physical aggression ${ }^{(25-26)}$.

Overall, the way students practice and suffer bullying changes throughout development. In childhood, physical aggression prevails. In adolescence, there were more relational and indirect aggressions ${ }^{(27)}$. Perhaps this is because adolescents better understand the harmful nature of bullying or because their aggressions can be interpreted by teachers as having greater severity and thus, bullies might receive more severe punishment ${ }^{(28)}$, which contributes to aggressions occurring in an increasingly subtle and implicit way, which makes it difficult to identify them and, consequently, to hold the offenders responsible. The finding that physical aggression is practiced in larger numbers in the investigated schools in this study may indicate that maybe it is not interpreted by a normative bias by school authorities and colleagues who do not consider it harmful and, therefore, do not repudiate their occurrence. Thus, intervention initiatives are needed to raise awareness among teachers and colleagues about the negative aspects of violence, as well as to sensitize them to position themselves in favor of non-violence ${ }^{(29)}$, such as the Theater of the Oppressed's proposal.

In this regard, a study on dating violence, which used the Theater of the Oppressed as an intervention strategy, identified an increase in self-reflections about the topic and promotion of non-violent responses, characterizing itself as a recommended strategy for use in studies aimed at the reduction of violence among adolescents $^{(18)}$. The Theater of the Oppressed induces the participant to reflect on their conflicts, to improve dialogic and corporal expression, and to stimulate active participation and autonomy ${ }^{(19,30-31)}$. Thus, the active participation of those involved, the promotion of creativity, critical/reflexive thinking and the expression of the singularity of adolescents promote their empowerment as the protagonist of their actions, more active and autonomous in overcoming their difficulties. The results of the present study corroborate these claims, since direct (physical and verbal) victimization reduced meaningfully in IG after the Theater of the Oppressed.

Boal's Theater of the Oppressed is directly connected to Paulo Freire's Pedagogy of the Oppressed and, therefore, has as its main mechanism of action the liberation of the oppressed ${ }^{(20)}$. Thus, the first moment of a social transformation is marked, initially, by the action of the oppressed in unveiling the world of oppression through its practice and alteration of conduct ${ }^{(20)}$. In this perspective, victimization reduction may be directly related to the behavior change of the victims of bullying, after the intervention, that they began to uncover their oppression, discovering the nature of bullying, the means by which it can be faced, and growing free of fear of acting against oppression, through the solutions presented and available in their daily lives ${ }^{(32)}$.

It is also important to highlight that the fact that the intervention in the present study did not have a significant effect on the reduction of aggressions and indirect physical and relational victimization can be justified by the local context of the school belonging to IG. During intervention, there was a tendency of bullying in its direct physical form. The themes and scenes suggested and staged by the adolescents in the Forum presented mainly situations of aggression and direct physical victimization, perhaps because they were considered more serious by students and school staff. In this respect, other researchers point out that direct aggression represents a form of bullying that is more evident in the school community, probably because its manifestations are more visible in the eyes of those who practice it, suffer its consequences or witness it ${ }^{(33-34)}$.

Concerning the effect of direct aggression intervention, in Mexico, a similar situation was identified in the present study. After the intervention, there was a reduction in bullying in frequency and intensity, but the aggression in its direct form did not decrea$\mathrm{se}^{(35)}$. In Brazil, researchers identified a reduction of aggressions in their direct form, but the intervention had a palliative effect, reducing bullying only for a few days and weeks ${ }^{(36)}$. However, other researchers who used multidimensional anti-bullying 
interventions, including activities other than dramatization and involvement of other social actors besides adolescents, such as teachers, parents and other professionals, identified a reduction in direct aggression shortly after the intervention ${ }^{(37-39)}$.

Brazil has nationally advanced in studies, with the purpose of testing forms and strategies to combat and prevent school violence. However, there is still a lack of intervention studies in the prevention of bullying specifically ${ }^{(1)}$. Therefore, the Theater of the Oppressed can be taken as a concrete possibility of prevention and coping with this phenomenon in schools, especially considering that the consequences of bullying go beyond physical damage, including other emotional losses, such as depression, suicidal ideation, school evasion, attention deficit, anxiety disorders, interference in social and family relationships, among others that may last until adulthood ${ }^{(40)}$. Other anti-bullying interventions developed with dramatization also showed positive results ${ }^{(17,41)}$ proving the effectiveness of this type of intervention.

\section{Study limitations}

The results of the present study should be interpreted considering some limitations. The first is that the post-intervention evaluation occurred immediately after the end of the actions of the Theater of the Oppressed. The most indicated procedure would have been the existence of a longer time lapse, since behavioral changes require more time to be effective in social relations. Another limitation is related to the tool used in data collection that does not include cyberbullying among the investigated variables, a type of aggression that has increased in the present time, due to the greater access of the students to the Internet and the greater anonymity that this type of aggression provides ${ }^{(42)}$. Future research may overcome these limitations by taking longer time between pre-intervention and post-intervention measures and by using tools for data collection that also measure the occurrence of cyberbullying. In addition, the present study did not contemplate an analysis of adolescents' impressions regarding the intervention and what were bullying coping strategies, after the educational practice with the theatrical methodology used. Despite the identified limitations, intervention based on the Theater of the Oppressed was statistically successful in reducing short-term bullying, especially considering that during the transition period, as discussed in this study, more aggressions occur.

\section{Contributions to Nursing and Health}

It is important to emphasize that the quality of social interactions between children and adolescents in schools and situations of violence, such as bullying, are relevant themes not only for education, but also for health and nursing. Bullying thus emerges as a cross-sectional theme that requires the adoption of intervention strategies that promote the individual empowerment of students, changing the way in which relationships are established in the educational environment as a collective space $^{(43)}$. This is an important perspective for health education and health promotion practices in school, since individual empowerment allows the development of (collective) community empowerment, exerting positive effects on students' learning, health and quality of life $\mathrm{e}^{(44)}$. Improvements in the quality of students' social interactions can be developed by nurses as a stimulus to establishing a culture of non-violence in schools. Therefore, there would be a reduction in the occurrence of bullying, especially considering that the intersectoral action of these professionals in the area of violence against children and adolescents still presents itself as a challenge ${ }^{(44)}$. This study brings new contributions, as it inserts the possibility of nurses acting through an intersectional practice directed by integral care that is based on actions within a dialogic and critical model of health education. The Theater of the Oppressed thus emerges as a strategy that can be incorporated into the practice of nursing professionals in intersectoral work.

\section{CONCLUSION}

Direct victimization reduced meaningfully in the group that participated in the intervention based on the Theater of the Oppressed. It was evidenced that it is a methodology that can help positively in actions for prevention of and coping with bullying among school adolescents, by favoring empowerment of students through the improvement of interactions and quality of life in schools. Thus, it is necessary that the areas of education and health, especially nursing in Primary Care, as social practices, contribute to scientific knowledge production in the field of school violence, expand their knowledge, appropriate new theories and practices. In schools, (re)build a model of child and adolescent care that works in prevention and decrease of bullying.

\section{FUNDING}

This study was supported by the Research Support Foundation of the State of Mato Grosso (FAPEMAT - Fundação de Amparo à Pesquisa do Estado de Mato Grosso) through a PhD scholarship (Process 152854/2015), and supported by grant 2018/04570-0 from the São Paulo Research Foundation (FAPESP).

\section{REFERENCES}

1. Pigozi PL, Machado AL. Bullying during adolescence in Brazil: an overview. Ciênc Saúde Colet. 2015;20(11):3509-22. doi: $10.1590 / 1413-812320152011.05292014$

2. Fonseca FF, Sena RKR, Santos RLA, Dias OV, Costa SM. The vulnerabilities in childhood and adolescence and the Brazilian public policy intervention. Rev Paul Pediatr. 2013;31(2):258-64. Doi: 10.1590/S0103-05822013000200019

3. Zappe JG, Dell'Aglio DD. Variáveis pessoais e contextuais associadas a comportamentos de risco em adolescentes. J Bras Psiquiatr. 2016;65(1):44-52. doi: 10.1590/0047-2085000000102 
4. Nesello F, Sant'Anna FL, Santos HG, Andrade SM, Mesas AE, González AD. Características da violência escolar no Brasil: revisão sistemática de estudos quantitativos. Rev Bras Saúde Matern Infant. 2014;14(2):119-36. doi: 10.1590/S1519-38292014000200002

5. Zequinão MA, Cardoso AA, Silva JL, Medeiros P, Silva MAI, Pereira B, et al. Academic performance and bullying in socially vulnerable students. J Hum Growth Dev. 2017;27(1):19-27. doi: 10.7322/jhgd.127645

6. Olweus D. School bullying: development and some important challenges. Annu Rev Clin Psychol. 2013;9:751-80. doi: 10.1146/ annurev-clinpsy-050212-185516

7. Weber LND, Dessen MA. Pesquisando a família: instrumentos para a coleta e análise de dados. Curitiba: Juruá; 2009.

8. Oliveira WA, Silva MAI, Silva JL, Mello FCM, Prado RR, Malta DC. Associations between the practice of bullying and individual and contextual variables from the aggressors' perspective. J Pediatr (Rio J). 2016;92(1):32-9. doi: 10.1016/j.jped.2015.04.003

9. Craig W, Harel-Fisch Y, Fogel-Grinvald H, Dostaler S, Hetland J, Simons-Morton B, et al. A cross-national profile of bullying and victimization among adolescents in 40 countries. Int J Public Health. 2009;54(Suppl 2):216-24. doi: 10.1007/s00038-009-5413-9

10. Silva JL, Oliveira WA, Braga IF, Farias MS, Lizzi EAS, Fagundes MG, et al. The effects of a skill-based intervention for victims of bullying in Brazil. Int J Environ Res Public Health. 2016;13(11):1042. doi: 10.3390/ijerph13111042

11. Garaigordobil M, Martínez-Valderrey V, Maganto C, Bernarás E, Jaureguizar J. Efectos de Cyberprogram 2.0 en factores del desarrollo socioemocional. Pensam Psicol. 2016;14(1):33-47. doi: 10.11144/Javerianacali.PPSI14-1.ecfd

12. Mello FCM, Malta DC, Prado RR, Farias MS, Alencastro LCS, Silva MAI. Bullying and associated factors in adolescents in the Southeast region according to the National School-based Health Survey. Rev Bras Epidemiol. 2016;19(4):866-77. doi: 10.1590/1980-5497201600040015

13. Instituto Brasileiro de Geografia e Estatística (IBGE). Pesquisa Nacional de Saúde do Escolar (PENSE) 2015 [Internet]. Rio de Janeiro: IBGE; 2016 [cited 2017 Aug 30]. Available from: https://biblioteca.ibge.gov.br/visualizacao/livros/liv97870.pdf

14. Pereira BO, Cost PJ, Melim FM, Farenzena RC. Bullying escolar: programas de intervenção preventiva. In: Gisi ML, Ens RT, organizadores. Bullying nas escolas - Estratégias de intervenção e formação de professores. ljuí: Editora UNIJUÍ; 2011. p.135-55.

15. França CB. O Jornal Vivo como aquecimento no role-playing do papel de educador. Rev Bras Psicodrama [Internet]. 2015 [cited 2017 Aug 30];23(1):75-81. Available from: http://pepsic.bvsalud.org/pdf/psicodrama/v23n1/n1a10.pdf

16. Kalinowski CE, Massoquetti RMD, Peres AM, Larocca LM, Cunha ICKO, Gonçalves LS, et al. Metodologias participativas no ensino da administração em Enfermagem. Interface (Botucatu). 2013;17(47):959-67. doi: 10.1590/S1414-32832013005000029

17. Joronen K, Häkämies A, Astedt-Kurki P. Children's experiences of a drama programme in social and emotional learning. Scand J Caring Sci. 2011;25(4):671-8. doi: 10.1111/j.1471-6712.2011.00877.x

18. Belknap RA, Haglund K, Felzer H, Pruszynski J, Schneider J. A Theater Intervention to prevent teen dating violence for Mexican-American Middle School students. J Adolesc Health. 2013;53(1):62-7. doi: 10.1016/j.jadohealth.2013.02.006

19. Oliveira ECS, Araújo MF. Aproximações do Teatro do Oprimido com a psicologia e o psicodrama. Psicol Ciênc Prof. 2012;32(2):340-55. doi: $10.1590 /$ S1414-98932012000200006

20. Baraúna, T. Considerações sobre a Pedagogia do Oprimido de Paulo Freire a Metodologia do Oprimido de Augusto Boal. In: Ligério Z, Turle L, Andrade C, organizadores. Augusto Boal: arte, pedagogia e política. Rio de Janeiro: Mauad X; 2013. p. 187-206.

21. Boal A. Teatro do Oprimido e outras poéticas políticas. São Paulo: Cosac Naify; 2013.

22. Dutra HS, Reis VN. Experimental and quasi-experimental study designs: definitions and challenges in nursing research. J Nurs UFPE On Line. 2016;10(6):2230-41. doi: 10.5205/reuol.9199-80250-1-SM1006201639

23. Boal A. Jogos para atores e não atores. São Paulo: Cosac Naify; 2015.

24. Trevisol MTC, Uberti L. Bullying na escola: a compreensão do aluno no papel de testemunha. Psicol Teor Prát. 2015;17(3):164-76. doi: 10.15348/1980-6906/psicologia.v17n3p00-00

25. Becker SP, Mehari KR, Langberg JM, Evans SW. Rates of peer victimization in young adolescents with ADHD and associations with internalizing symptoms and self-esteem. Eur Child Adolesc Psychiatry. 2017;26(2):201-14. doi: 10.1007/s00787-016-0881-y

26. Arango A, Opperman KJ, Gipson PY, King CA. Suicidal ideation and suicide attempts among youth who report bully victimization, bully perpetration and/or low social connectedness. J Adolesc. 2016;51:19-29. doi: 10.1016/j.adolescence.2016.05.003

27. Silva JL, Oliveira WA, Bazon MR, Cecílio S. Bullying na sala de aula: percepção e intervenção de professores. Arq Bras Psicol [Internet]. 2013 [cited 2017 Sep 12];65(1):121-37. Available from: http://pepsic.bvsalud.org/scielo.php?script=sci_arttext\&pid=S1809-52672013000100009

28. Mello FCM, Silva JL, Oliveira WA, Prado RR, Malta DC, Silva MAI. The practice of bullying among Brazilian schoolchildren and associated factors, National School Health Survey 2015. Ciênc Saúde Colet. 2017;22(9):2939-48. doi: 10.1590/1413-81232017229.12762017

29. Silva JL, Oliveira WA, Mello FCM, Andrade LS, Bazon MR, Silva MAI. Anti-bullying interventions in schools: a systematic literature review. Ciênc Saúde Colet. 2017;22(7):2329-40. doi: 10.1590/1413-81232017227.16242015

30. Silva JJS, Silva PMC, Azevedo EB, Ferreira Filha MO, Cordeiro RC. Desvelando os caminhos do teatro do oprimido como estratégia de reabilitação psicossocial. Rev Pesqui Cuid Fundam Online. 2011;(Supl.):164-75. doi: 10.9789/2175-5361.2011.v0iSupl..164-175

31. Oliveira ECS, Araújo MF. O Teatro Fórum como dispositivo de discussão da violência contra a mulher. Estud Psicol (Campinas). 2014;31(2):257-67. doi: 10.1590/0103-166X2014000200011 
32. Mavroudis N, Bournelli P. The role of drama in education in counteracting bullying in schools. Cogent Educ. 2016;3(1):1233843. doi: $10.1080 / 2331186 X .2016 .1233843$

33. Dalosto MM, Alencar EMLS. Manifestações e prevalência de bullying entre alunos com altas habilidades/superdotação. Rev Bras Educ Espec. 2013;19(3):363-78. doi: 10.1590/S1413-65382013000300005

34. Paixão GPN, Santos NJS, Matos LSL, Santos CKF, Nascimento DE, Bittencourt IS, et al. Violência escolar: percepções de adolescentes. Rev Cuid. 2014;5(2):717-22. doi: 10.15649/cuidarte.v5i2.83

35. Sánchez RY. Intervención educativa para resolver un caso de acoso escolar. Psicol Esc Educ. 2013;17(2):339-54. doi: 10.1590/ S1413-85572013000200016

36. Santos AM, Grossi PK, Scherer PT. Bullying nas escolas: a metodologia dos círculos restaurativos. Educação (Porto Alegre) [Internet]. 2014 [cited 2018 Jul 03]; 37(2):278-87. Available from: http://revistaseletronicas.pucrs.br/ojs/index.php/faced/article/view/14495

37. Mendes CS. Preventing school violence: an evaluation of an intervention program. Rev Esc Enferm USP. 2011;45(3):580-7. doi: 10.1590/ S0080-62342011000300005

38. Nese RNT, Horner RH, Dickey CR, Stiller B, Tomlanovich A. Decreasing Bullying Behaviors in Middle School: Expect Respect. Sch Psychol Q. 2014;29(3):272-86. doi: 10.1037/spq0000070

39. Stelko-Pereira AC, Williams LCA. Evaluation of a Brazilian School Violence Prevention Program (Violência Nota Zero). Pensam Psicol. 2016;14(1):63-76. doi: 10.11144/Javerianacali.PPSI14-1.ebsv

40. Silva JL, Oliveira WA, Bono EL, Dib MA, Bazon MR, Silva MAI. Associações entre bullying escolar e conduta infracional: revisão sistemática de estudos longitudinais. Psic Teor Pesq. 2016;32(1):81-90. doi: 10.1590/0102-37722016012241081090

41. Fredland NM. Nurturing healthy relationships through a community-based Interactive Theater Program. J Community Health Nurs. 2010;27(2):107-18. doi: 10.1080/07370011003705013

42. Lee C, Shin N. Prevalence of cyberbullying and predictors of cyberbullying perpetration among Korean adolescents. Comput Human Behav. 2017;68:352-8. doi: 10.1016/j.chb.2016.11.047

43. Silva MAI, Silva JL, Pereira BO, Oliveira WA, Medeiros M. The view of teachers on bullying and implications for nursing. Rev Esc Enferm USP. 2014;48(4):723-30. doi: 10.1590/S0080-623420140000400021

44. Carlos DM, Pádua EMM, Silva LMP, Silva MAI, Marques WEU, Leitão MNC, et al. The care network of the families involved in family violence against children and adolescents: the Primary Health Care perspective. J Clin Nurs. 2017;26(15-16):2452-67. doi: 10.1111/jocn.13692 